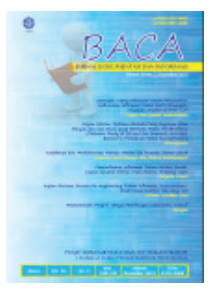

\title{
PENERAPAN KNOWLEDGE MANAGEMENT: ORAL HISTORY PENANGANAN ARSIP BENCANA TOPAN HAIYAN DI FILIPINA
}

\author{
Aris Riyadi ${ }^{1 *}$; Afdini Rihlatul Mahmudah²; Diah Budhi Utami ${ }^{3}$ \\ ${ }^{1}$ Perpustakaan Nasional Republik Indonesia \\ ${ }^{2 \& 3}$ Pasca-Sarjana Program Studi Ilmu Perpustakaan - Universitas Indonesia \\ *Korespondensi: aris_ryd@yahoo.com/aris.riyadi@ui.ac.id
}

Diajukan: 5-3-2016; Direview: 15-6-2016; Diterima: 10-8-2016; Direvisi: 22-9-2016

\begin{abstract}
Knowledge management process using Nonaka's SECI model in creation of knowledge can provide guidance for learning and developing activities. Nevertheless, understanding the process of socialization, externalization, combination and internalization needs to be deepened with a lot of practice directly. This article provides a framework for real method that synthesizes basic phases as informal knowledge from an expert who has never capture and promotes knowledge before. Purpose of this article is to open earlier tacit knowledge form into process of socialization and internalization. An expert knowledge how to handling damage records by natural disaster will revealed in explicit way through capture process of oral history. Process for document damage recovery is conducted using disaster management procedure or library materials preservation knowledge. Research method for knowledge capture carried through pre-interview, interview and post-interview. Support data such as form of images, diaries, letters, agreements and others are used to reinforce methodology. Applying this method will produce two knowledge directly which are disaster management knowledge and management knowledge processes.
\end{abstract}

\begin{abstract}
ABSTRAK
Manajemen Pengetahuan menggunakan model SECI Nonaka dalam penciptaan pengetahuan dapat memberi bimbingan untuk situasi dan kegiatan belajar. Namun, pemahaman dalam proses sosialisasi, eksternalisasi, kombinasi dan internalisasi perlu diperdalam dengan banyak melakukan praktek langsung. Artikel ini memberikan kerangka kerja nyata melalui metode yang mensintesis fase dasar berupa pengetahuan informal seorang ahli yang belum pernah dilakukan tahap penangkapan dan pengembangan pengetahuan sebelumnya. Tujuan dari artikel ini adalah membuka pengetahuan yang sebelumnya berupa tacit untuk masuk ke dalam proses sosialisasi dan internalisasi. Pengetahuan narasumber dalam penanganan arsip akibat bencana alam akan ditampilkan secara eksplisit melalui proses penangkapan sejarah lisan. Prosedur yang digunakan dalam perbaikan dokumen dilakukan menggunakan pengetahuan manajemen bencana atau preservasi bahan perpustakaan. Metode yang digunakan dalam penangkapan pengetahuan dilakukan dengan cara pra wawancara, wawancara dan pasca wawancara. Data dukung yang berupa gambar, catatan harian, surat persetujuan dan lainnya digunakan untuk memperkuat metode yang digunakan. Dengan menerapkan metode ini maka akan diperoleh dua pengetahuan secara langsung berupa pengetahuan tentang penanganan bencana dan proses manajemen pengetahuan.
\end{abstract}

Keywords: Knowledge management; SECI; Oral history; Disaster management; Preservation of library materials 


\section{PENDAHULUAN}

Perkembangan manajemen pengetahuan (knowledge management) belakangan ini terlihat semakin gencar dilakukan tidak hanya dalam ranah wacana teori saja melainkan aplikasi langsung pada banyak intitusi industri maupun lembaga dokumentasi dan informasi. Hal ini dirasa menjadi kebutuhan saat ini bagaimana komunitas mengelola pengetahuannya. Penciptaan dan difusi pengetahuan adalah faktor yang sangat penting sebagai komoditas dan aset intektual dalam menciptakan produk atau cara kerja tertentu yang dilakukan oleh pekerja. Sebuah institusi akan memperoleh kemajuan ketika pengetahuan yang secara kolektif diketahui kemudian dilakukan secara berkelanjutan, seberapa efisien pemanfaatannya, dan seberapa cepat penciptaan dan penggunaan pengetahuan baru. Institusi dalam era informasi dan pengetahuan adalah organisai belajar, mengingat, dan bertindak berdasarkan informasi, pengetahuan, dan ketrampilan yang tersedia.

Manajemen pengetahuan awalnya didefinisikan sebagai proses menerapkan pendekatan sistematis untuk menangkap, menata, mengelola, dan menyebarkan pengetahuan di seluruh organisasi untuk bekerja lebih cepat, menggunakan kembali praktik terbaik, dan mengurangi biaya yang mahal dari satu proyek ke proyek lain (Nonaka dan Takeuchi, 1995; Pasternack dan Viscio 1998; Pfeffer dan Sutton, 1999; Ruggles dan Holtshouse, 1999). Dalam suatu organisasi, mengelola pengetahuan biasanya sudah dilakukan namun jumlahnya mungkin tidak banyak dan hanya sebatas pada standar operasional yang sangat singkat dan tidak memberikan informasi yang cukup detail. Bahkan terkadang sambil lalu saja dikarenakan kesibukan dan ketidakpedulian pihak manajemen tentang ilmu yang dimiliki oleh seorang pegawai non-manajemen. Pengetahuan tidak harus dimiliki oleh orang-orang yang memiliki jabatan atau otoritas tinggi namun yang pasti, ia memiliki kompetensi dan spesialisasi terhadap ilmunya. Pengetahuan yang dimiliki oleh setiap individu dalam organisasi merupakan salah satu bentuk dari pengetahuan tacit yang masih terdapat dalam benak pemilik pengetahuannya. Pengelolaan pengetahuan adalah kegiatan untuk mengubah pengetahuan tacit menjadi pengetahuan eksplisit sehingga dapat diketahui dan dimanfaatkan oleh orang lain secara luas.

Peran pusat informasi dan perpustakaan dalam manajemen bencana atau kondisi darurat bukan topik yang sederhana dan dipandang sebelah mata terutama pada negara-negara yang rawan bencana termasuk di Indonesia (negara kepulauan). Pekerjaan utama pustakawan sudah saatnya pula lebih kompleks dengan mengekplorasi peran mereka secara professional dalam memitigasi dan menangani koleksi akibat bencana. Pekerja informasi harus dapat andil berinisiatif dalam menddik dan memberi kesadaran kepada masyarakat mengenai pengurangan dampak potensi bencana terhadap arsip dan bahan pustaka yang dimiliki. Tanggung jawab seorang pustakawan atau ilmuwan informasi adalah menjaga dan melestarikan sumber informasi berharga dan tak ternilai baik dalam bentuk tercetak maupun tidak. Bencana alam yang terjadi secara alami maupun buatan sangat berpotensi merusak infrastruktur dan koleksi tersimpan. Akibat lebih lanjutnya adalah memutus akses pada generasi yang akan datang, maka pada saat itulah terputus pula kebudayaan dan pengetahuan dalam perjalanan sejarah suatu bangsa. Hal inilah yang membuat penting suatu lembaga informasi memiliki sistem pengelolaan bencana.

Bencana alam apapun bentuknya adalah ancaman yang bisa menghancurkan dokumen. Ancaman bisa terjadi langsung maupun tidak langsung. Arsip yang dimiliki oleh seseorang seperti halnya nyawa kedua bagi pemiliknya karena merupakan wakil identitas atas diri dan harta yang telah mereka peroleh selama hidupnya. Dalam penanganan korban bencana di Filipina, perhatian terhadap korban jiwa dan harta demikian tinggi, simpati mengalir dari berbagai pihak. Relawan berbondong-bondong membantu korban, tak terkecuali Indonesia. Indonesia menerjunkan relawan disamping untuk menyelamatkan para korban juga turut andil menyelamatkan arsip berupa surat-surat penting seperti surat tanah milik masyarakat, sertifikat, dokumen kantor dan lain-lain. Tidak disadari arsip merupakan bagian penting dalam kehidupan modern. Sebagai recorded information yang memiliki berbagai bentuk, arsip menjadi sisi yang tidak terpisahkan dari kehidupan manusia. Satu hal yang tidak dapat diabaikan bahwa arsip terkait dengan status dan hak, baik individu maupun lembaga. Sebagai contoh, kasus akte tanah dalam kaitannya dengan bencana menunjukkan bahwa arsip terkait erat dengan status dan hak kepemilikan dan pemanfaatan atas wilayah di suatu negara.

Dampak buruk kerusakan bencana dapat diperparah ketika manusia tidak dapat melakukan 
perencanaan tentang terjadinya bencana. Sebagai contoh penempatan struktur bangunan yang lebih rendah dari permukaan laut atau bangunan gedung yang dekat dengan sumber air seperti laut, sungai, dan danau maka akan sangat besar kemungkinan terkena dampak bencana banjir. Negara-negara kepulauan dipastikan sangat rentan mengalami dampak buruk dari datangnya bencana, salah satunya adalah angin topan. Pada tahun 2012 topan Haiyan menyerbu sejumlah wilayah di Filipina. Dampaknya sangat dahsyat, korban tewas diperkirakan mencapai 10 ribu orang. Ribuan rumah hancur rata tersapu angin super kencang. Topan 'monster' ini telah melalap habis 6 pulau di Filipina. Banyak bangunan dan perumahan yang hancur, sebagian besar korban tewas terjadi di Pulau Leyte. Bencana ini juga membuat aktivitas warga lumpuh. Listrik mati dan jalur transportasi tak bisa dilalui. Besarnya efek dari Topan Haiyan ini disamakan dengan bencana tsunami pada 2004 silam yang menimpa kawasan Samudra Pasifik, di mana dampak terbesar terjadi di Aceh.

Para ilmuwan mengatakan Topan Haiyan merupakan salah satu dari badai terkuat yang pernah mencapai daratan. Beberapa ahli mengatakan perubahan iklim akibat ulah manusia adalah penyebabnya. Bob Ward, ilmuwan dari Lembaga Riset Grantham untuk Perubahan Iklim di London School of Economics, mengatakan ada bukti situasional yang kuat karena kita tahu bahwa kekuatan siklon tropis, badai dan topan sangat bergantung pada suhu-suhu permukaan laut. Pada tahun itu pula seorang sukarelawan dari Indonesia dikirim untuk membantu menangani dokumen berupa arsip-arsip yang tersimpan oleh pemerintah lokal (land administration) dimana tugasnya menerbitkan dan menyimpan surat tanah dan histori tanah kepimilikan penduduk setempat. Sukarelawan tersebut banyak memiliki pengalaman dan pengetahuan tentang penanganan dokumen yang rusak akibat bencana alam hanya saja pengetahuannya tidak tersosialisasikan dengan baik dan tidak terdokumentasikan dalam bentuk pengetahuan eksplisit. Sangat disayangkan bahwa peristiwa dan ilmu tentang penanganan dokumen akibat bencana alam topan Haiyan ini tidak dapat dibagikan dalam bentuk formal dan tertulis. Pengetahuan tentang pengelolaan bencana lebih banyak dimiliki oleh negara-negara maju yang memang dahulu mengembangkan teknologi dan sistem manajemen yang mapan seperti Jepang, Amerika, dan Kanada. Hal ini disebabkan oleh intensitas bencana yang menimpa negara tersebut sehingga membuat ilmuwan mereka banyak mengembangkan pengetahuaannya. Namun, buat negara asia tenggara sendiri terutama Indonesia masih sangat kecil pengetahuan dan manajemen yang dimiliki berkaitan dengan preservasi dokumen.

\section{TINJAUAN PUSTAKA}

Artikel ini akan memperluas wacana manajemen pengetahuan (KM) melalui aplikasi yang kongkrit dan mengenal beberapa dasar-dasar manajemen pengetahuan. Manajemen pengetahuan merupakan bidang kajian mengelola pengetahuan di dalam organisasi yang pada kenyataannya kepemilikan pengetahuan sebenarnya berada pada individu-individu di dalamnya. Menurut Land (2008), terdapat dua aspek yang dipertimbangkan dalam KM. Pertama, pengetahuan dikelola dengan maksud digunakan sebagai alat untuk mencapai beberapa tujuan, kadang-kadang eksplisit, tetapi sering tersembunyi atau diam-diam. Kami mencatat bahwa tujuan tidak selalu jelas, dan memiliki sisi gelap dari manajemen pengetahuan, termasuk pengetahuan dan informasi manipulasi. Kedua, pengetahuan yang telah dikelola sejak manusia menciptakan pidato dan bahwa beberapa kegiatan bertujuan tidak mencakup beberapa unsur manajemen pengetahuan.

\section{1. Model Dinamika Pengetahuan Nonaka}

Menurut Gourlay (2004), Nonaka (1994) memandang dua dimensi dalam penciptaan pengetahuan, yaitu dimensi epistemologis dan dimensi ontologis. Dimensi pertama terkait dengan konversi pengetahuan dari tingkat tacit ke level eksplisit dan dari tingkat eksplisit ke tingkat tacit. Dimensi kedua terkait dengan konversi pengetahuan dari individu untuk kelompok hingga ke tingkat organisasi. Menggabungkan dua tahapan ini Nonaka mendapat model spiral untuk penciptaan dan pengolahan pengetahuan. Nonaka membuat asumsi dasar yang merupakan inti dari model SECI. Asumsi tersebut mengatakan bahwa pengetahuan diciptakan melalui konversi antara pengetahuan tacit dan eksplisit yang memungkinkan kita untuk mendalilkan empat model berbeda dari konversi pengetahuan: (1) dari pengetahuan tacit ke pengetahuan tacit; (2) dari pengetahuan eksplisit ke pengetahuan eksplisit; (3) 
dari pengetahuan tacit ke pengetahuan eksplisit; dan (4) dari pengetahuan eksplisit ke pengetahuan tacit (Nonaka, 1994).

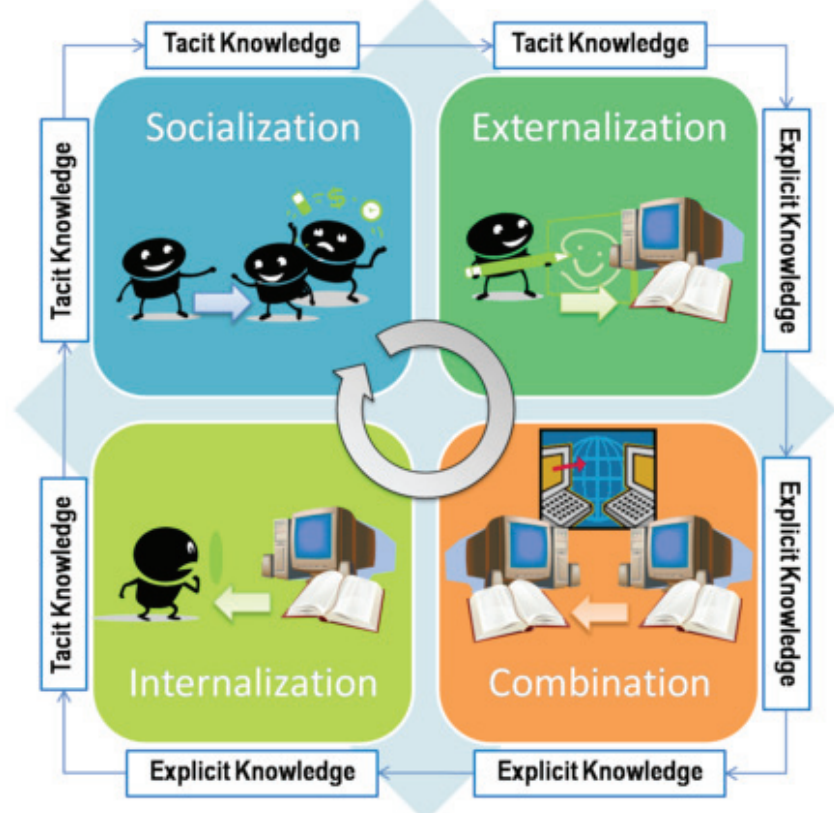

Gambar 1. Model SECI (Nonaka, 1994)

Proses pertama, menciptakan pengetahuan tacit melalui pengalaman bersama disebut sosialisasi. Pengetahuan tacit biasanya sulit untuk dilakukan formalitas dan untuk diekspresikan menggunakan bahasa. Ini adalah konteks terkait. Seperti halnya proses seseorang belajar magang ketrampilan melalui observasi dan imitasi dari para ahli. Proses kedua adalah hasil interaksi sosial melalui bahasa. Proses ini menciptakan pengetahuan eksplisit dari pengetahuan eksplisit lainnya yang disebut kombinasi. Proses ketiga berbeda dari yang sebelumnya karena melibatkan kedua jenis pengetahuan atau transformasi pengetahuan. Proses transformasi didasarkan pada gagasan bahwa pengetahuan tacit dan eksplisit adalah dua bentuk pengetahuan yang saling melengkapi dalam interaksi secara terus menerus. Proses ketiga adalah transformasi pengetahuan tacit menjadi pengetahuan eksplisit yang kemudian disebut eksternalisasi. Keberhasilan proses ini tergantung pada penggunaan berurutan dari metafora, analogi dan model (Nonaka, Toyama \& Byosiere, 2001). Proses ke empat berurusan dengan transformasi pengetahuan eksplisit menjadi pengetahuan tacit atau disebut internalisasi. Proses ini mewujudkan pengetahuan eksplisit sebagai pengetahuan tacit. Hal ini erat dengan "learning by doing".

Tiga proses pertama terkait pandangan Nonaka untuk pembelajaran organisasi, sedangkan yang terakhir terkait dengan pembelajaran individu. Berdasarkan ide-ide di atas, Nonaka menyimpulkan bahwa organisasi menciptakan pengetahuan secara terus menerus dengan restrukturisasi dasar pengetahuan yang ada melalui sinergi dari empat proses dasar transformasi pengetahuan. Artinya, pusat penciptaan pengetahuan terjadi pada pembangunan baik pengetahuan tacit dan eksplisit, dengan kata lain proses yang lebih penting adalah pertukaran antara kedua aspek pengetahuan melalui internalisasi dan eksternalisasi (Nonaka, 1994).

\section{2. Proses Konversi Pengetahuan}

Organisasi memiliki keduanya baik proses pengetahuan struktural maupun informal yang mengisi satu sama lain. Proses pengetahuan struktural, artinya telah mengalami alur perencanaan, terorganisir dan pengumpulan tersistematis dan selanjutnya berbagi pengetahuan. Di sisi lain, proses pengetahuan informal merupakan cara spontan dan sukarela mengumpulkan dan berbagi pengetahuan. Sebagai contoh, ketika dalam sebuah rapat maka para manajer sering memperoleh pengetahuan dari manajer yang 
lain melalui kedua kegiatan struktural seperti pertemuan formal dan laporan. Selain itu, beberapa manajer memperoleh pengetahuan melalui kegiatan informal seperti melakukan pembicaraan dengan rekan-rekan lainnya (Maltz \& Kohli, 1996). Proses struktural dan informal menghasilkan pengetahuan yang memfasilitasi pembelajaran organisasi (Akgun, Lynn \& Byrne, 2003; Argote, McEvily \& Reagan, 2003; Holsapple \& Jones, 2004; Huber, 1991; Young, 1998).

Pengetahuan tacit merupakan aspek penting dari pembelajaran organisasi. Juga, proses pengetahuan informal yang mempromosikan pengetahuan tacit. Sehingga hal ini menunjukkan bahwa proses pengetahuan informal setidaknya sama pentingnya dengan proses pengetahuan struktural (Swap et al., 2001). Lahti, Darr dan Krebs (2002) menunjukkan bahwa transfer pengetahuan informal sangat mempengaruhi kinerja organisasi. Ini memberikan indikasi efektivitas proses pengetahuan informal organisasi belajar. Oleh karena itu, proses informal pengetahuan seperti sosialisasi dan internalisasi yang penting bagi organisasi belajar yang efektif. Salah satu kelemahan pada pengetahuan tacit informal bahwa pengetahuan tersebut hanya melekat pada pemilik pengetahuannya sepanjang hidupnya sehingga apabila pemiliknya sudah tiada maka pengetahuan akan hilang pula. Oleh karena itu sangat penting untuk segera melakukan sosialisasi dan eksternalisasi agar pengetahuan dapat tetap lestari.

Menurut Schuman (1987), pengetahuan tidak hanya ada pada pikiran seseorang. Agar tercipta proses kreasi pengetahuan, sebuah konteks spesifik dibutuhkan, dalam pengertian waktu, tempat, dan hubungan antar individu (dalam Sedenghi \& Banan: 2009, 1185). Kreasi pengetahuan memerlukan konteks. Tanpa konteks, tidak akan ada pengetahuan baru yang muncul di dalam suatu organisasi, sehingga konteks pengetahuan merupakan bagian penting dari proses inovasi. Konteks ini adalah "platform" di mana pengetahuan dibagikan, dikreasi dan digunakan. Nonaka, Toyama, dan Konno (2001:21-25) mengajukan empat konteks penciptaan pengetahuan:

1) Konteks Originating

Konteks pengetahuan ini berupa interaksi tatap muka antar individu, di mana masing-masing individu saling bcrbagi pengalaman, perasaan, emosi dan model mental. Proses konversi pengetahuan yang terjadi di dalam konteks interaksi ini didominasi modus sosialisasi.

2) Konteks Dialoguing

Konteks pengetahuan ini bcrupa interaksi tatap muka antar individu yang bersifat kolektif. Pola interaksi tercipta dengan terencana dan lebih disadari oleh orang yang terlibat di dalamnya. Biasanya orang yang terlibat interaksi mcrupakan orang "terpilih", gabungan dari pengetahuan dan kemampuan yang bcrbeda. Dalam tipe interaksi ini individu saling berbagi model mental dan keahlian, kemudian dikonversi menjadi istilah bcrsama dan diartikulasikan dalam bentuk konsep. Proses konversi pengetahuan yang terjadi di dalam konteks ini didominasi modus eksternalisasi.

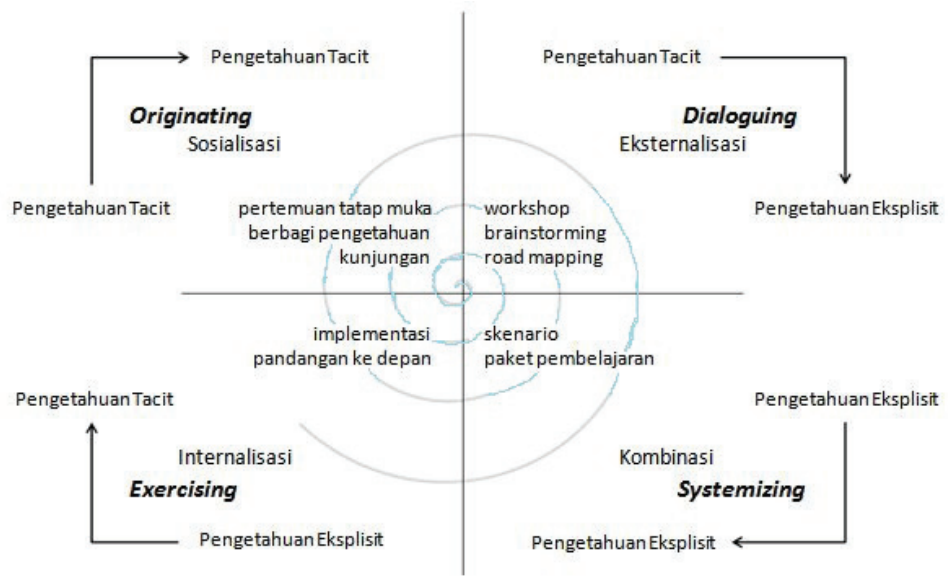

Gambar 2. Konversi dan penciptaan pengetahuan baru 
3) Konteks Systemizing

Tipe ini didefiniskan sebagai interaksi virtual dan bersifat kolektif. Proses konversi pengetahuan yang terjadi di dalam konteks interaksi ini didominasi modus kombinasi. Konteks ini lebih efektif jika didukung dengan pemanfaatan teknologi informasi seperti internet, milis, database atau semacamnya.

4) Konteks Exercising

Interaksi yang bersifat individual dan virtual, di mana individu mewujudkan (embody) pengetahuan eksplisit yang dikomunikasikan melalui media visual, seperti manual atau program simulasi. Proses konversi pengetahuan yang terjadi di dalam konteks interaksi ini didominasi modus internalisasi.

Komponen terpenting kreasi pengetahuan adalah proses berbagi pengetahuan antara individu yang terdapat di dalam organisasi. Kegiatan berbagi pengetahuan berlangsung di datam konteks interaksi di mana setiap proses interaksi akan menghasilkan pcngetahuan baru baik dalam bentuk eksplisit maupun tacit melalui proses konversi pengetahuan. Dari pengetahuan baru itulah muncul inovasi bagi organisasi. Pcngetahuan baru yang dihasilkan dari interaksi antar individu memungkinkan organisasi mengenali perubahan yang terjadi di dalam lingkungannya dan secara kreatif menciptakan cara baru yang beradaptasi dalam bentuk inovasi.

\section{3. Alasan Pemilihan Topik dan Narasumber}

Untuk menangani arsip akibat bencana alam dibutuhkan seseorang yang mampu melakukan tindakan agar arsip tidak mengalami kerusakan yang semakin parah. Seseorang yang memiliki keahlian dalam penanganan arsip bisa disebut sebagai conservator. Seseorang yang melakukan upaya penyelamatan arsip dilakukan dalam rangka menjamin keselamatan dan kelestarian arsip. Profesi konservator kertas khususnya untuk perpustakaan masih sangat langka, padahal sangat dibutuhkan dalam mengemban tugas melestarikan bahan pustaka koleksi sebuah perpustakaan (Indah, 2013). Djulianto (2010) mengatakan bahwa konservator dalam menangani arsip kertas, yang sulit dilakukan adalah menemukan huruf atau kata yang hilang. Jika sudah diperoleh, barulah kertas-kertas tersebut di-laminating. Teknik laminating merupakan cara yang efektif untuk melestarikan dokumen agar bisa bertahan dalam jangka waktu selama mungkin.

Dalam rangka penyelamatan arsip akibat bencana Topan Haiyan, Perpustakaan Nasional mengirim conservator (1 orang) dengan keahlian yang dimiliki ke Filipina. Beberapa pertimbangan yang mendasari pemilihan informan tersebut sebagai berikut.

- Satu-satunya conservator di Perpustakaan Nasional RI yang dikirim ke Filipina untuk menangani arsip akibat bencana Topan Haiyan. Beberapa karya yang sudah dihasilkan, seperti beberapa buku tentang perencanaan kesiapan dalam menghadapi bencana dan artikel-artikel yang ditulis tentang preservasi.

- Memiliki kredibilitas pengetahuan mengenai preservasi dokumen fisik yang diperoleh dari pendidikan formal serta pengalaman. Memiliki kompetensi skill manajemen bencana di bidang preservasi dokumen fisik salah satunya dalam perbaikan dokumen akibat kerusakan bencana alam menggunakan teknologi canggih maupun manual.

- Memiliki jaringan kerjasama dengan beberapa relawan atau conservator di dalam dan luar negeri. Hasil kerjasama yaitu sebuah MOU antar-negara ASEAN dalam bidang Preservasi Perpustakaan dan Arsip.

- Aktif dalam kegiatan penanggulangan bencana koleksi perpustakaan dan banyak berdiskusi dengan sejumlah pakar di bidang preservasi koleksi dan budaya, seperti Belfor, Canada dan Polygon, USA.

Tulisan ini ingin meng-capture bagaimana informan menangani dan menyelamatkan arsip penting, yaitu surat-surat tanah milik masyarakat Filipina yang terkena dampak bencana alam Topan Haiyan, dengan pengetahuan dan kesaksian yang beliau miliki. 


\section{METODE}

Metode yang digunakan adalah wawancara. Pertanyaan wawancara disusun untuk menggambarkan dan mendalami semua kegiatan yang dilakukan oleh narasumber dalam melakukan kegiatannya sebagai conservator pada saat me-recovery arsip di Filipina akibat bencana Topan Haiyan. Untuk menguatkan otentisitas dari hasil wawancara maka kami melakukannya dengan menggunakan perekaman sound recorder dan video.

\section{1. Pre-Interview}

Interviewer Guidelines, USC Shoah Foundation Institute University of Southern California, menjelaskan bahwa sebelum wawancara, pewawancara melakukan preinterview. Tujuan pre-Interview untuk: (a) menemui dan menjalin hubungan dengan interviewee; (b) menjelaskan format wawancara; (c) meninjau peralatan /logistik wawancara; (d) mengumpulkan fakta-fakta dasar tentang kehidupan interviewee; dan (e) mengisi pertanyaan pre-interview.

\subsubsection{Membuat penyusunan pre-interview}

Pre-interview biasanya dilakukan sekitar satu minggu sebelum wawancara. Pewawancara didorong untuk melakukan pre-interview langsung, biasanya di rumah yang diwawancara. Jika tatap muka tidak memungkinkan, pre-interview dapat dilakukan melalui telepon. Pewawancara seharusnya sensitif mengenai waktu yang pantas untuk menelepon dan tidak menelepon pada hari libur agama, terlalu pagi atau terlalu malam.

\subsubsection{Mengatur nada pada saat pre-interview}

Membangun kepercayaan dan hubungan dengan yang diwawancarai penting untuk keberhasilan wawancara. Untuk pewawancara, hubungan ini dimulai dengan kontak pertama. Pewawancara harus berusaha menemukan keseimbangan yang tepat antara pendekatan kekeluargaan dan pendekatan formal. Sikap hormat, rileks, dan ramah seharusnya diterapkan dan dipertahankan selama berhubungan dengan yang diwawancara. Pakaian merupakan komponen penting dalam sikap dan perilaku dan pewawancara harus berpakaian resmi, profesional dan nyaman. Pewawancara harus memahami kesensitifan budaya yang berkaitan dengan cara berpakaian yang pantas.

\subsubsection{Dokumen pre-interview}

Pewawancara membawa dua dokumen untuk pre-interview, yaitu pertanyaan pre-interview dan release agreement (persetujuan rilis).

a. Pertanyaan pre interview

Pertanyaan pre-interview dirancang untuk mengumpulkan informasi biografi spesifik tentang yang diwawancarai, dan berfungsi sebagai petunjuk untuk pewawancara. Informasi yang dikumpulkan dari pertanyaan pre-interview adalah "road map" nya pewawancara untuk memahami cerita kehidupan yang diwawancara. informasi tersebut memberikan pewawancara mengenai kronologis umum tentang kehidupan yang diwawancarai, juga nama-nama keluarga dekat, nama tempat di mana yang diwawancarai tumbuh, informasi tentang latar belakang pendidikan, sosial dan agama. Pewawancara harus mengisi pertanyaan pre-interview dan juga menggunakan itu untuk mengkonfirmasi ejaan nama dan lokasi.

Pertanyaan pre-interview memandu penelitian dan persiapan pewawancara untuk wawancara sebenarnya. Dalam oral history "Penanganan Dokumen Pasca Bencana Topan Haiyan di Filipina", kami melakukan persiapan pertanyaan yang membantu kami dalam wawancara sebenarnya. Pertanyaan ini kami kirimkan melalui email ke narasumber. Berikut contoh pertanyaan yang kami kirimkan melalui email. 


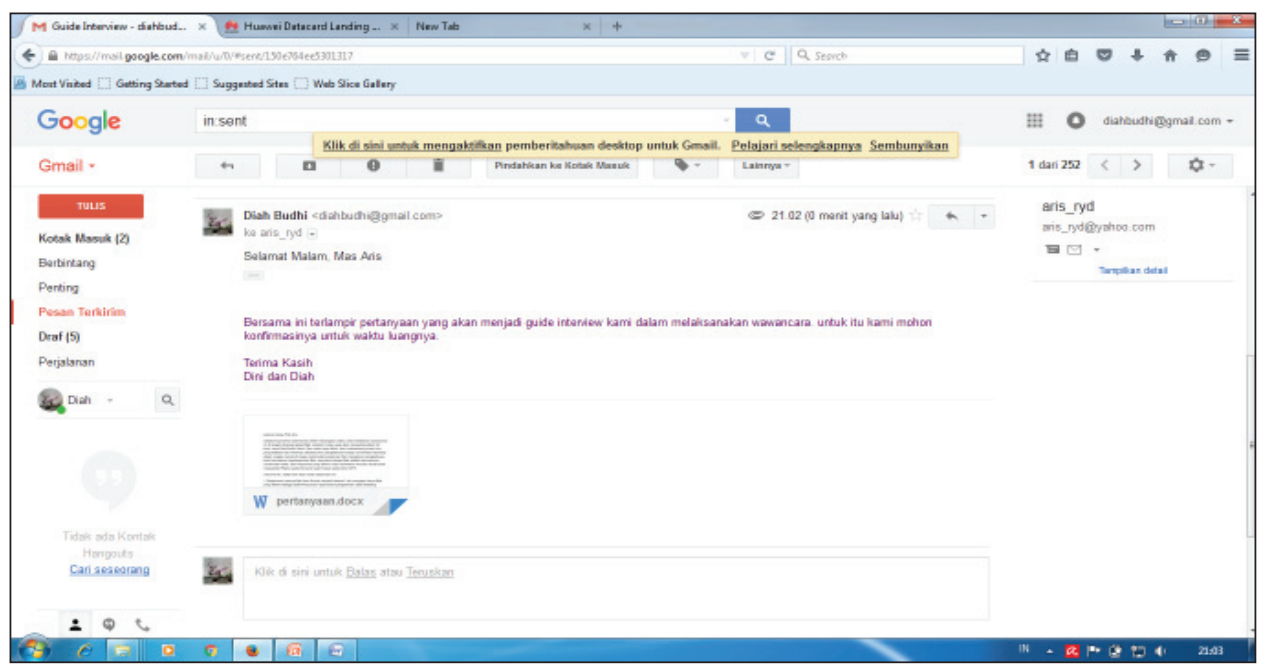

Gambar 3. Pertanyaan yang dikirimkan kepada narasumber melalui e-mail.

Daftar pertanyaan pre-interview yang diajukan sebagai berikut. Tabel 1. Daftar Pertanyaan Pre-Interview

\begin{tabular}{|c|l|}
\hline No. & \multicolumn{1}{|c|}{ Pertanyaan } \\
\hline 1. & $\begin{array}{l}\text { Latar belakang keilmuan apa sehingga ditempatkan di bagian preservasi } \\
\text { Perpustakaan Nasional RI? }\end{array}$ \\
\hline 2. & Sudah berapa lama bekerja di bagian preservasi Perpusnas? \\
\hline 3. & Apa saja job desk seorang konservator? \\
\hline 4. & $\begin{array}{l}\text { Menurut kompetensi apa saja yang harus dimiliki oleh seorang conservator } \\
\text { khususnya dalam hal penanganan arsip di suatu negara akibat bencana alam? }\end{array}$ \\
\hline 5. & $\begin{array}{l}\text { Mengenai peristiwa topan Haiyan di Filipina pada tahun 2012, bagaimana } \\
\text { prosesnya hingga bisa diminta untuk ikut menangani recovery surat berharga } \\
\text { penduduk di sana? }\end{array}$ \\
\hline 6. & Bagaimana kondisi surat-surat berharga tersebut ketika melakukan recovery? \\
\hline 7. & $\begin{array}{l}\text { Apa saja yang dilakukan untuk mengembalikan kondisi surat-surat berharga } \\
\text { tersebut? }\end{array}$ \\
\hline 8. & Kendala apa saja yang dihadapi di sana? \\
\hline 9. & Apakah tantangan terbesar yang temukan di sana? \\
\hline 10. & $\begin{array}{l}\text { Bagaimana cara berbagi pengetahuan dan pengalaman dengan rekan kerja di } \\
\text { Perpusnas? }\end{array}$ \\
\hline 11. & apakah ada kendala dalam berbagi pengetahuan dengan rekan kerja? \\
\hline 12. & $\begin{array}{l}\text { apakah bermaksud untuk mendokumentasikan pengetahuan dan pengalaman } \\
\text { selama di sana? }\end{array}$ \\
\hline
\end{tabular}

b. Persetujuan rilis (release agreement)

Saat pre-interview, Release Agreement diberikan kepada interviewee untuk dilihat. Dua salinan asli Release Agreement ditandatangani oleh interviewee dan anggota keluarga manapun sebelum muncul di kamera. Interviewee dan anggota keluarga, jika relevan, menyimpan satu salinan. Release Agreement yang kami buat (terlampir) merupakan permohonan izin wawancara kepada narasumber. Dikarenakannarasumberadalah konservator diLingkungan Perpustakaan Nasional RI, maka kami memohon izin wawancara kepada pimpinan narasumber, yaitu 
Penanggung jawab narasumber selaku Kepala Pusat Preservasi Bahan Pustaka dan juga yang menugaskan narasumber untuk menangani penanganan dokumen pasca bencana Topan Haiyan di Filipina. Dalam surat itu tertera persetujuan rilis hasil rekaman dan wawancara. Surat itu ditandatangani oleh Kepala Pusat Preservasi Bahan Pustaka, Perpustakaan Nasional dan wakil pewawancara. Release Agreement ini ada dua, yaitu untuk Kepala Pusat Preservasi Bahan Pustaka dan pewawancara. Berikut adalah cara pembagian tugas pre interview dalam kelompok.

Tabel 2. Daftar Pertanyaan Pre-Interview

\begin{tabular}{|c|l|c|}
\hline No. & \multicolumn{1}{|c|}{ Deskripsi Tugas } & Pelaksana (X, Y, Z) \\
\hline 1 & Menyusun oral history project proposal & $\mathrm{X}, \mathrm{Y}, \mathrm{Z}$ \\
\hline 2 & Menyusun guide interview & $\mathrm{Y}, \mathrm{Z}$ \\
\hline 3 & Membuat appoinment dengan informan & $\mathrm{Y}, \mathrm{Z}$ \\
\hline 4 & Mempersiapkan MoU & $\mathrm{Y}, \mathrm{Z}$ \\
\hline 5 & Mempersiapkan kamera & $\mathrm{X}$ \\
\hline 6 & Mempersiapkan video recorder & $\mathrm{X}$ \\
\hline 7 & Melaksanakan wawancara & $\mathrm{X}, \mathrm{Y}, \mathrm{Z}$ \\
\hline 8 & Melakukan transkrip & $\mathrm{X}, \mathrm{Y}, \mathrm{Z}$ \\
\hline 9 & Mengolah data video & $\mathrm{X}$ \\
\hline 10 & Analisis data & $\mathrm{X}, \mathrm{Y}, \mathrm{Z}$ \\
\hline 11 & Pembuatan Laporan oral life history project & $\mathrm{X}, \mathrm{Y}, \mathrm{Z}$ \\
\hline
\end{tabular}

Berikut ini adalah bukti percakapan dengan narasumber untuk pre-interview melalui aplikasi Whatsapp.

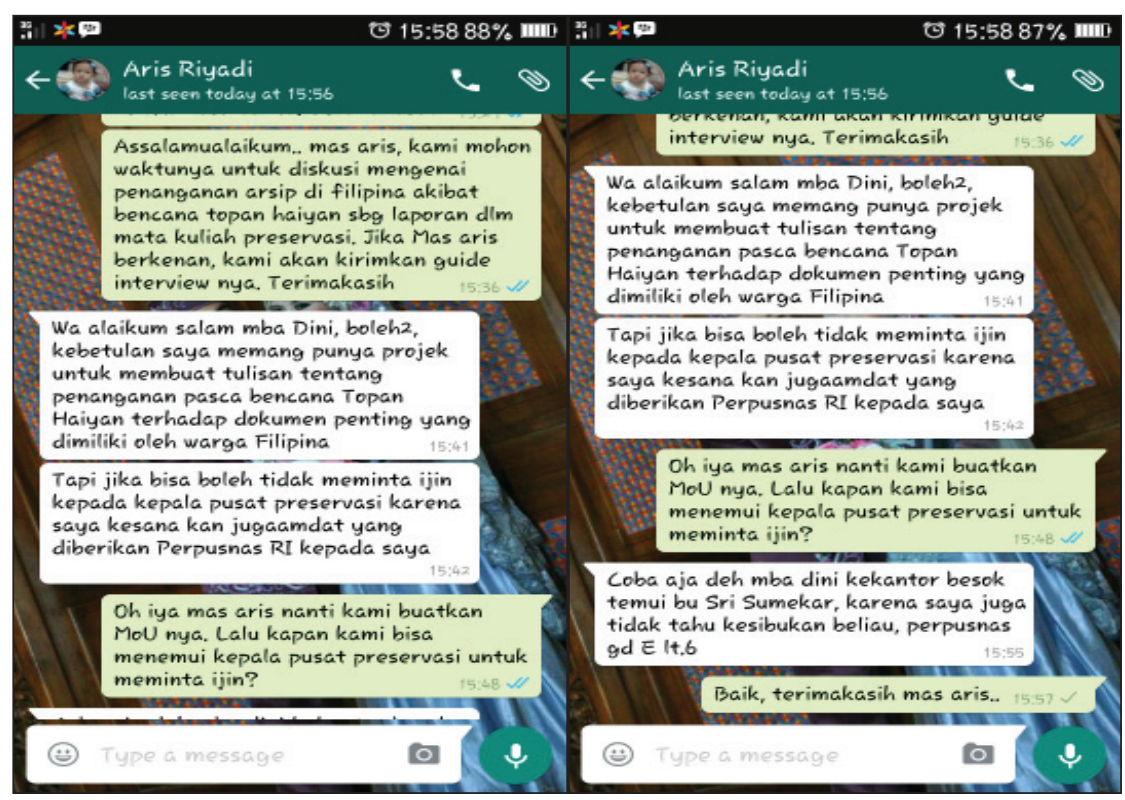

Gambar 4. Proses percakapan tim dengan narasumber 


\section{2. Interview}

Wawancara memerlukan pewawancara yang rendah hati, sensitif, dan sopan. Gaya pertanyaan pewawancara sangat penting untuk seorang profesional yang akan di wawancara. Wawancara yang ideal terdiri dari pertanyaan terbuka yang memungkinkan kesaksian yang di wawancarai mengalir. Interviewer Guidelines, USC Shoah Foundation Institute University of Southern California menjelaskan bahwa teknik wawancara:

- Pewawancara diinstruksikan untuk menghindari sesi "tanya jawab". Seperti bertanya dengan pertanyaan "apakah Anda," "bisakah Anda,". Pewawancara menggunakan kalimat pembuka-akhiran seperti "ceritakan tentang," atau "tolong jelaskan." Pewawancara mendorong yang diwawancara untuk berbicara panjang lebar dengan gaya narasi, serta berbagi reaksinya untuk apa dia menyaksikan.

- Pewawancara dilatih untuk menghindari mengajukan pertanyaan serta pertanyaan multisectioned, jauh lebih baik untuk mengajukan satu pertanyaan pada satu waktu.

- Pewawancara didorong untukmenggunakan pertanyaan yang memperjelas, penyelidikan, dan tindak lanjut untuk memperoleh keterangan lebih lanjut. Pertanyaan klarifikasi digunakan untuk memeriksa ejaan, tanggal, dan untuk membangun kerangka waktu dari peristiwa yang dijelaskan. Penyelidikan pertanyaan memperoleh informasi secara lebih mendalam, dan dimanfaatkan untuk meminta responden untuk merenungkan peristiwa. Pertanyaan tindak lanjut mendorong responden untuk menguraikan topik yang relevan yang telah disebutkan hanya sebentar dalam kesaksian tersebut.

- Jika yang diwawancarai tidak bisa mengingat fakta khusus atau tentang pengalamannya, atau suatu historis yang tidak akurat (misalnya, tanggal atau fakta yang tidak benar), pewawancara harus menahan diri dan langsung mengoreksi yang diwawancara. Sebagai gantinya, pewawancara didorong untuk mencoba memverifikasi informasi yang benar, dengan mengajukan pertanyaan klarifikasi, atau untuk menyelidiki lebih dalam untuk memicu memori.

- Pewawancara dilatih untuk tidak menghakimi atau berasumsi bahwa mereka tahu apa yang responden akan katakan selanjutnya.

- Pewawancara diinstruksikan untuk menghindari suara terdengar seperti "uh huh," "umm," "benar," "ya," dan lain-lain yang umum dalam percakapan sehari-hari. Pewawancara harus memperhatikan untuk tidak mengganggu atau berbicara atas responden; senyap atau jeda adalah cara yang paling efektif untuk memperoleh informasi dari orang yang diwawancara. Hal tersebut juga memungkinkan waktu responden untuk berpikir, merenung, dan mengingat kenangan/memori.

- Komentar pewawancara (kecuali pertanyaan) harus disimpan. Komunikasi nonverbal bagaimanapun adalah sangat penting. Menganggukkan kepala, menggunakan gerakan tangan, dan mempertahankan kontak mata mendorong responden untuk melanjutkan, dan menunjukkan responden bahwa pewawancara penuh perhatian dan ikut terlibat.

- Kadang-kadang responden berbicara tentang orang-orang atau tempat yang tidak didokumentasikan pada kuesioner pre-interview. Pewawancara diinstruksikan untuk mencoba dan menuliskan nama-nama selama wawancara, sambil mempertahankan kontak mata. Setelah wawancara selesai, pewawancara harus memverifikasi ejaan nama-nama dengan responden dan memasukkan informasi ini dalam informasi postinterview.

- Karena wawancara direkam secara keseluruhan dan tidak diedit, rekaman video harus terus jika responden menjadi emosional atau kebutuhan saat mengumpulkan pikiran. Pewawancara harus terus menggunakan komunikasi nonverbal daripada mencoba untuk menghibur responden secara lisan. Untuk memastikan integritas, wawancara tidak boleh berhenti kecuali dalam kasus darurat atau jika responden benar-benar tidak dapat melanjutkan.

- Jika responden menjadi sangat emosional, pewawancara harus tetap duduk dan terus mendengarkan, bahkan jika ada jeda panjang dan keheningan. Pewawancara harus terus menggunakan komunikasi nonverbal dan menahan diri dari dorongan untuk menggunakan isyarat verbal untuk menghibur responden, seperti "tidak apa-apa" atau "aku mengerti." Wawancara dapat dihentikan hanya jika responden menegaskan, 
pewawancara tidak harus menyarankan itu.

- Mungkin ada saat-saat wawancara ketika pengalaman yang diwawancarai akan membuat pewawancara tidak nyaman dan mungkin sangat sulit untuk mendengar. Di situasi seperti itu, reaksi alami pewawancara untuk cerita dapat diterima, selama itu tidak mengganggu yang diwawancarai. Hal ini penting untuk pewawancara menjadi sadar sendiri dan fokus

pada responden dan alur dari wawancara.

- Dalam kasus di mana orang yang diwawancara menulis puisi, memainkan musik, seni yang dihasilkan, dan lain-lain. Selama perang, pewawancara dapat mendorong yang diwawancara untuk berbagi pada kamera. Pewawancara selalu bertanya apakah yang diwawancara ingin berbagi pada akhir wawancara. Kadang-kadang kronologi cerita dapat terganggu dan cerita menjadi jelas. Pewawancara kemudian harus meminta klarifikasi dengan mengatakan, "tolong koreksi saya jika saya telah salah paham, tapi yang anda katakan ...?", "dan kemudian anda pergi untuk ...?" atau "katakan sekali lagi, yang ...? Jika sesuai, pewawancara harus meminta tanggal yang tepat. Dalam kasus ketika yang diwawancara sedang berjuang dan tidak ingat kata atau terjemahan dari kata, pewawancara harus sabar memberikan responden kesempatan untuk mengingat. Jika orang yang diwawancara tidak ingat dan pewawancara tahu maka harus mengatakannya.

\subsubsection{Wawancara}

Sebuah catatan atau daftar ditampilkan pada kamera di awal wawancara. Catatan termasuk data, seperti tanggal wawancara, nama responden, nama saat lahir, nama pewawancara, kota, negara bagian atau provinsi di mana wawancara yang sedang dilakukan, dan bahasa wawancara. Dalam melakukan wawancara tim akan melakukan verifikasi terlebih dahulu keterangan, seperti:

- siapa nama anda (dan ejaan)?;

- siapa nama anda saat lahir (dan ejaan)?;

- apakah anda memiliki julukan sebagai seorang anak?;

- kapan tanggal lahir anda?;

- berapa usia anda saat ini?;

- apa kota anda (dan ejaan) dan negara kelahirannya?.

Setelah pertanyaan tersebut di atas, pewawancara meminta nama ayah yang diwawancarai, ibu (termasuk nama gadis), saudara (dan urutan kelahiran mereka), serta nama-nama orang dalam rumah tangga (anggota keluarga) dan kakek-nenek. Profesi dari ayah dan ibu dari orang yang diwawancara juga dicari dari wawancara.

\subsubsection{Perubahan rekaman}

Sekitar 1-2 menit sebelum akhir rekaman, tanda videografer pewawancara dengan cara nonverbal bahwa perubahan pita sudah dekat atau akan berakhir. Ini memungkinkan waktu untuk responden menyelesaikan pikirannya. Pewawancara kemudian memberitahukan putusnya rekaman (misalnya, "kita akan berhenti sekarang dan pindah ke rekaman berikutnya"). Pewawancara harus menggunakan putusan rekaman untuk memberikan responden dorongan dan untuk menunjukkan topik yang mungkin telah dihilangkan dan topik yang akan dibahas dalam rekaman berikutnya. Pada awal setiap rekaman, pewawancara harus memperkenalkan pita nama orang yang diwawancarai dan jumlah pita (misalnya, "wawancara dengan Max Smith, rekaman 2"). Setelah rekaman itu berlangsung, pewawancara mengingatkan yang diwawancara di mana dia meninggalkan off ketika rekaman terakhir berakhir: "Mr. Smith, Anda bicarakan .... ".

\subsubsection{Penutup wawancara}

Pewawancara menyimpulkan kesaksian dengan meminta yang diwawancarai jika ada hal lain yang ia ingin tambahkan yang belum tercakup dalam wawancara. Setelah pernyataan akhir, pewawancara menyimpulkan wawancara dengan sederhana "terima kasih." Setelah kamera dimatikan, pewawancara memverifikasi 
ejaan nama dan nama tempat geografis yang disebutkan selama wawancara dan tidak termasuk dalam kuesioner pre-interview. Informasi ini ditambahkan ke "informasi post-interview".

\subsubsection{Foto-foto dan bagian artefak}

Wawancara biasanya terdiri dari memorabilia keluarga dan kehidupan masyarakat, perang, pengalaman imigrasi, serta pascaperang dan foto kontemporer. Setelah wawancara, film videografer foto-foto, dokumen, artefak, dan/atau kenangkenangan. Produk yang biasanya disajikan dalam urutan kronologis. Setiap item difilmkan secara individual, sementara yang diwawancara menjelaskan item off camera. Deskripsi tentang bagaimana yang diwawancarai memperoleh foto atau artefak sering menghasilkan detil tambahan dan deskriptif tentang pengalaman hidup individu, mungkin tidak tercakup dalam wawancara itu sendiri. Pewawancara meminta yang diwawancara untuk mengidentifikasi setiap foto dengan cara sebagai berikut: (1) pertama dan nama terakhir dari orang dalam foto; (2) tanggal foto diambil; (3) tempat foto diambil; (4) bagaimana foto itu diperoleh; (5) informasi lain yang ingin berbagi oleh interviewee tentang item.

\subsubsection{Mengkonfirmasi kembali hasil wawancara}

Setelah proses wawancara yang pertama interviewee dapat meminta kepada interviewer untuk melakukan evaluasi tentang wawancara yang telah dilakukan sebelumnya sebagai koreksi keseluruhan peristiwa yang dibicarakan, hal ini dapat memberikan info tentang isi dari wawancara, intonasi, kualitas suara dan sebagai ingatan interviwee terhadap hal yang terlupakan atau apa yang belum ia sebutkan dengan komplit. Berikut konfirmasi hasil wawancara yang kami kirimkan melalui WhatsApp ke narasumber.

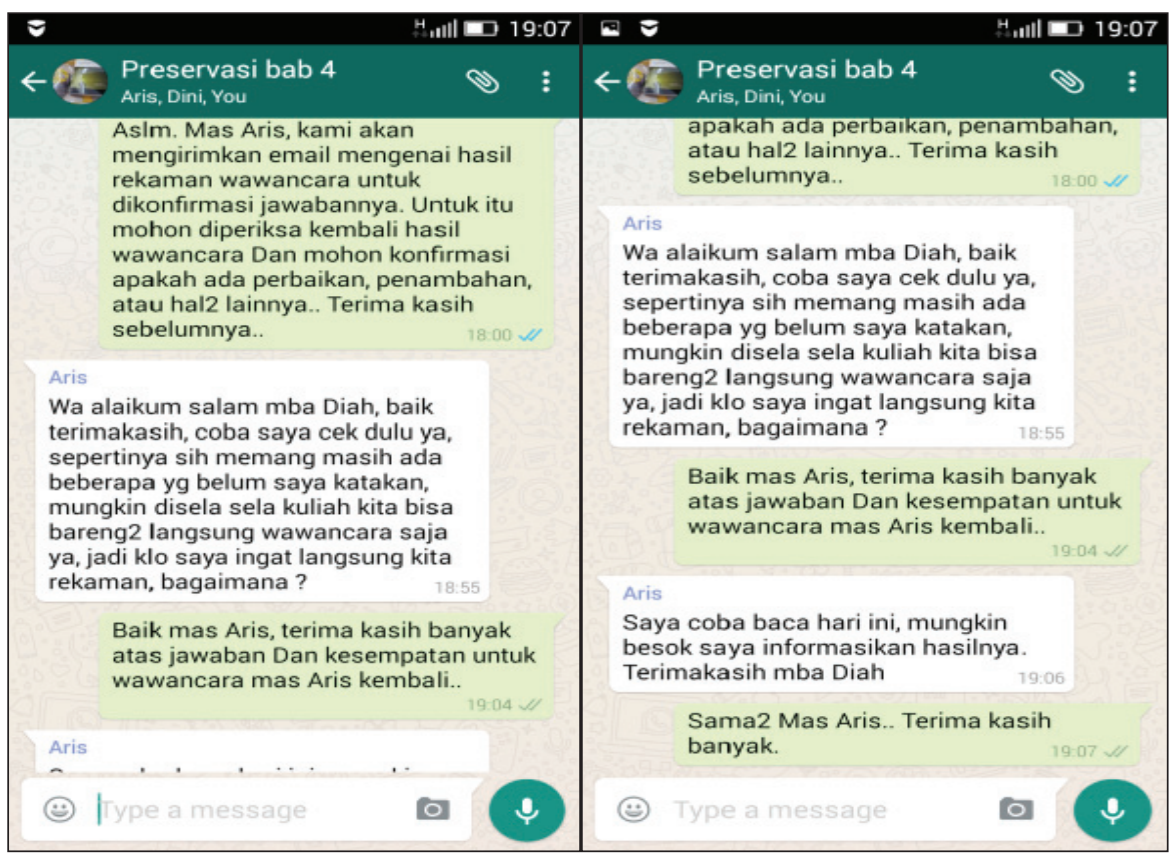

Gambar 5. Proses konfirmasi hasil wawancara dengan narasumber

\subsubsection{Mengingatkan tentang peristiwa yang terlupakan melalui wawancara mendadak}

Dalam proses menangkap pengetahuan tacit, interviewer sangat dituntut untuk melakukan pertanyaan lebih rinci sehingga pengetahuan yang terpendam di dalam si pemilik pengetahuan benar-benar dapat keluar. Menjaga untuk selalu berkomunikasi dan intensif berhubungan dapat mengingatkan pemilik pengetahuan untuk mengingat 
kembali hal yang terlupa yang ingin disampaikan oleh interviewee. Wawancara dapat dilakukan setiap saat bahkan dalam setting yang terlalu formal namun benarbenar mencerminkan keluarnya pengetahuan pada waktu itu juga tanpa perencanaan sebelumnya. Hal ini dapat mempermudah mengingat kembali pengetahuan yang sebelumnya tidak muncul. Berikut hal yang teringat oleh narasumber yang dikirim melalui WhatsApp ke pewawancara.

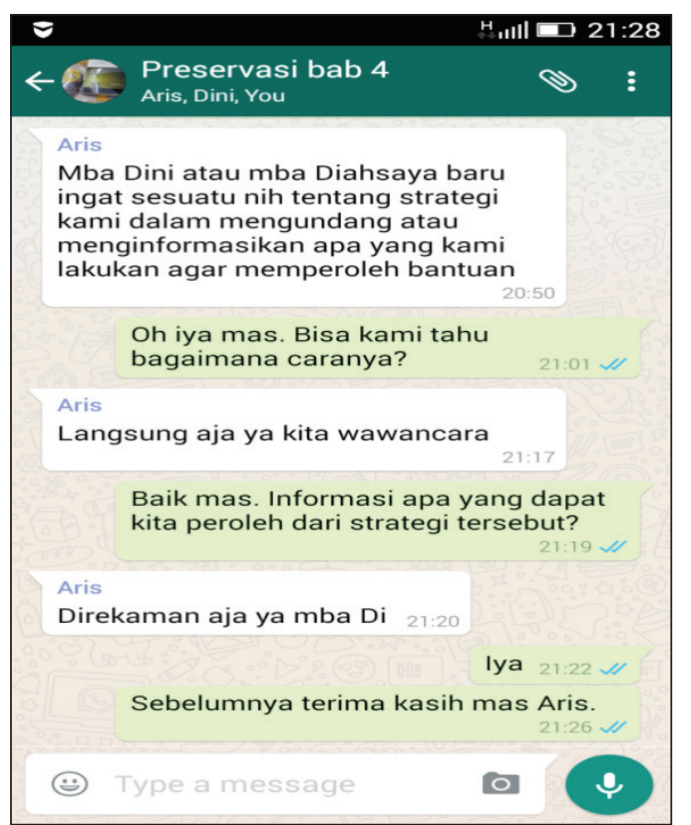

Gambar 6. Proses mengingat kembali peristiwa yang terlupa

\subsection{Pasca-Interview}

Setelah wawancara berakhir, pewawancara mengucapkan terima kasih kepada orang yang diwawancara dan memastikan bahwa kuesioner pre-interview telah benar dan sepenuhnya selesai. Pewawancara diinstruksikan untuk memanggil satu atau dua hari setelah wawancara kepada yang diwawancarai untuk kesaksiannya. Banyak pewawancara mengirim ucapan terima kasih. Seringkali, ikatan yang kuat dan persahabatan berkembang sebagai akibat dari pengalaman bersama selama proses wawancara. Proses wawancara juga dapat intens dan melelahkan bagi pewawancara. Pewawancara didorong untuk mempunyai waktu untuk diri mereka sendiri setelah wawancara.

\subsubsection{Mengelola media penyimpanan}

Media untuk menangkap pengetahuan dapat melalui rekaman suara, video dan video-suara. Intrumen tersebut sendiri mempunyai keunggulannya masing masing dan tidak harus satu metode yang digunakan. Ada kalanya manager menggunakan instrumen tunggal dan campuran. Banyaknya jumlah arsip dalam menangkap pengetahuan juga menuntut manager melakukan pengolahan data rekaman yang dapat dilakukan sesuai kepentingan masing-masing organisasi. Hal ini sangat penting agar deskripsi yang ada pada media menjadi identitas wakil dokumen dan nantinya dapat dengan mudah ditemukan kembali. Lim (2000:101) menjelaskan bahwa medium rekaman yang digunakan pada perekaman asli sama pentingnya dengan transkripsi, karena beragamnya pemakainya. Ada pengaruhnya bila orang hanya membaca teks atau transkrip. Teks dari suatu wawancara berguna sebagai bahan untuk mencari informasi. Bila perubahan-perubahan sosial dan kultural diperlukan, hubungan katakata suara rekaman bisa menjadi sangat penting. 
Dalam mengolah dokumen atau arsip rekaman kelompok kami menggunakan sistem pemberkasan dengan acuan sebagai berikut.

\section{AVOI1312001 atau AV-O-I-13-12-001}

(jenis koleksi-keaslian-bahasa-tahun-bulan-no urut)

Keterangan :

- AV untuk audio visual, $\mathrm{V}$ untuk video tanpa suara dan A untuk audio tanpa gambar;

- O untuk original (asli) dan C untuk copy (salinan);

- I untuk bahasa Indonesia dan A untuk bahasa asing yang digunakan di dalam arsip;

- Dua angka pertama setelah huruf adalah tahun diperolehnya arsip;

- Dua angka setelah dua angka pertama adalah bulan diperolehnya arsip;

- Tiga angka setelah empat angka pertama adalah nomer urut diperolehnya arsip.

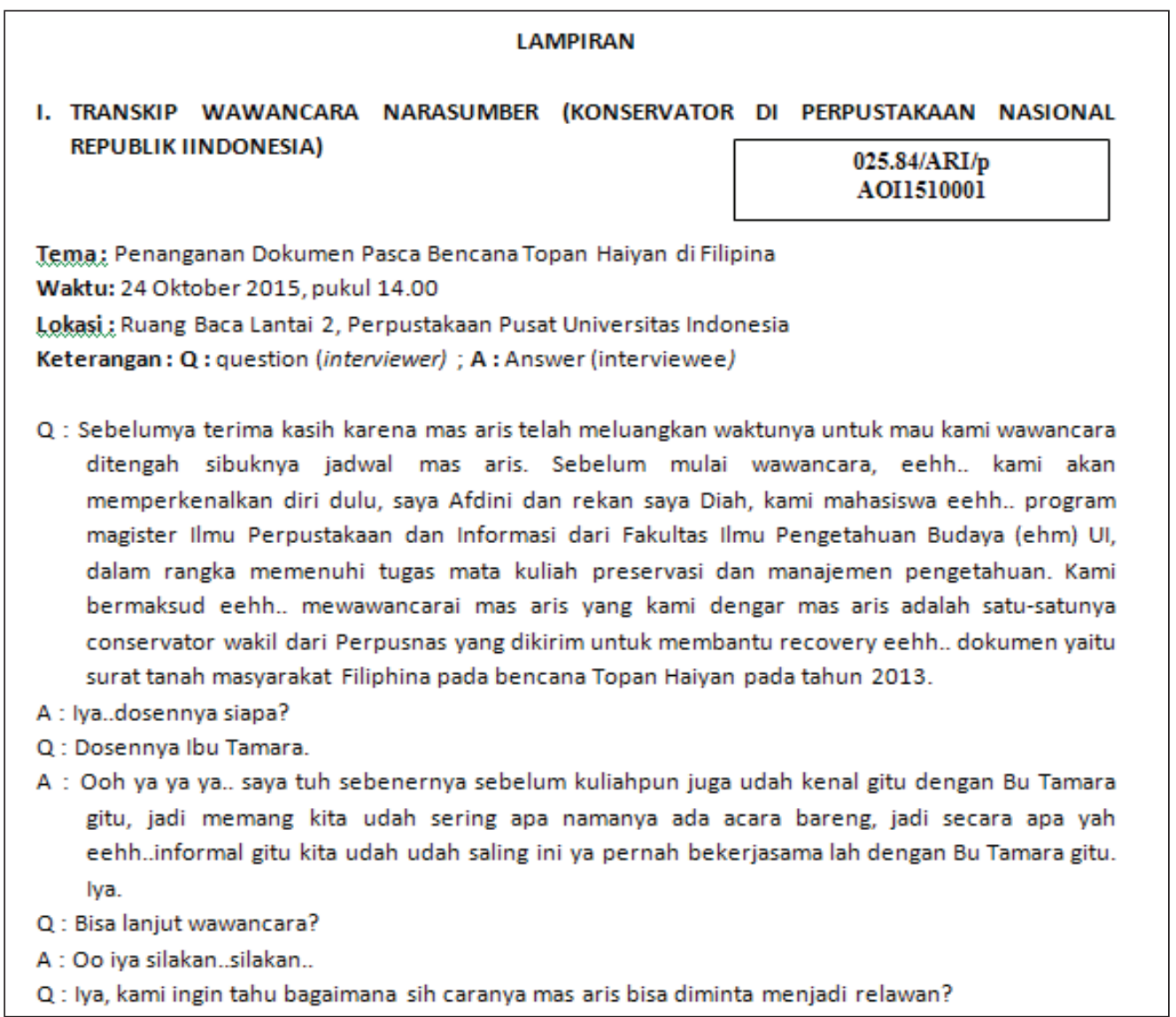

Gambar 7. Transcript contents I

Tabel 3. Daftar Transcript Contents I

\begin{tabular}{|c|c|c|c|}
\hline Project name & \multicolumn{3}{|c|}{ Penanganan Dokumen Pasca Bencana Topan Haiyan di Filipina } \\
\hline Number & \multicolumn{3}{|c|}{ AOI1510001 } \\
\hline File name & $\begin{array}{c}\text { Penanganan Dokumen Pasca Bencana Topan } \\
\text { Haiyan pada Land Administration }\end{array}$ & Interview date & $24-10-2015$ \\
\hline Interviewee & Narasumber & Gender & Laki-Laki \\
\hline
\end{tabular}




\begin{tabular}{|c|c|c|c|c|}
\hline Interviewer & $\mathrm{Y}, \mathrm{Z}$ & Reviewer & \multicolumn{2}{|c|}{$\mathrm{Y}, \mathrm{Z}, \mathrm{X}$} \\
\hline \multirow{2}{*}{$\begin{array}{c}\text { Subject } \\
\text { classification } \\
\text { code }\end{array}$} & \multicolumn{2}{|c|}{ 025.84/ARI/p } & Interview place & Perpustakaan Pusat, \\
\hline & \multicolumn{3}{|c|}{ Contents } & Pages \\
\hline Contents & \multicolumn{3}{|c|}{$\begin{array}{l}\text { Knowledge sharing } \\
\text { Perjalanan ke Takloban, Filipina } \\
\text { Kondisi pasca bencana } \\
\text { Adaptasi dengan kondisi pasca bencana } \\
\text { Pentingnya sebuah dokumen } \\
\text { Penanganan dokumen pasca bencana }\end{array}$} & $\begin{array}{l}1,2,25,26 \\
4,6,7,8,9,10,11 \\
12,13 \\
14,15 \\
16,17,18 \\
18,19,20,21\end{array}$ \\
\hline Keyword & \multicolumn{4}{|c|}{ Dokumen; konservasi; pasca bencana } \\
\hline
\end{tabular}

III. TRANSKIP WAWANCARA ARIS RIYADI (KONSERVATOR DI PERPUSTAKAAN NASIONAL RI)
Tema,: Penanganan Dokumen Pasca Bencana Topan Haiyan di Filipina
Waktu: 26 Oktober 2015, pukul 09.30
Lokasi: Gedung 7 Fakultas Ilmu Pengetahuan Budaya, Universitas Indonesia
Keterangan: Q : question (inteniewer); A : Answer (interviewee)
Q. : Mas aris kan sebelumnya pernah mengatakan bahwa mas aris akan mengikuti pertemuan
eehh..pertemuan tentang recovery di Indonesia ya.. nah, yang ingin saya tanyakan di Indonesia
ada ga sih orang yang selain mas aris itu eehh. dia concern terhadap penanganan atau recovery
dari dokumen pada saat bencana gitu atau setelah bencana pasca bencana?
A : Sebenarnya sih ada gitu ya, cuman jumlahnya tuh terbatas.. nah untuk yang dokumen sendiri itu
memang fokusnya ke mungkin ya yang institusi yang apa namanya berkaitan dengan dokumen,
kalau di Indonesia sih biasanya di ANRI kemudian di Perpustakaan Nasional gitu, sedangkan
untuk ahli-ahli yang tentang disaster itu sebenarnya banyak terutama orang-orang akademis
gitu, kalau yang kemarin saya temui sih beberapa orang sih memang banyak ya, doktor-doktor
gitu atau praktisi-praktisi gitu hanya saja memang apa namanya fokusnya itu ga ke dokumen
gitu, jadinya ya mungkin ilmu baru buat kita gitu, nah..disinilah mungkin kesempatan kita buat
mengembangkan itu, mengembangkan bagaimana cara eehh..apa namanya manajemen
penanggulangan bencana atau perencanaan sebelum terjadi bencana gitu, kalau kemarin yang
di eehh..di Jogja itu ya kita memang apa namanya mengundang orang-orang kayak arsitek gitu,
dosen-dosen gitu iya sih banyak lah bicara tentang apa namanya..bencana, bencana alam tapi

Gambar 7. Transcript contents II

Tabel 4. Daftar Transcript Contents II

\begin{tabular}{|c|c|c|c|}
\hline Project name & \multicolumn{3}{|c|}{ Penanganan Dokumen Pasca Bencana Topan Haiyan di Filipina } \\
\hline Number & \multicolumn{3}{|c|}{ AOI510002 } \\
\hline File name & $\begin{array}{c}\text { Kebutuhan Akan Konservator Dalam } \\
\text { Menangani Penanganan Bencana }\end{array}$ & Interview date & 26-10-2015 \\
\hline Interviewee & Narasumber & Gender & Laki-Laki \\
\hline Interviewer & $\mathrm{Y}, \mathrm{Z}$, & Reviewer & Y, Z,X \\
\hline
\end{tabular}




\begin{tabular}{|c|c|c|c|}
\hline $\begin{array}{l}\text { Subject } \\
\text { classification } \\
\text { code }\end{array}$ & 025.84/ARI/p & Interview place & $\begin{array}{l}\text { Gedung } 7 \text { Fak,Ilmu } \\
\text { Pengetahuan Budaya, } \\
\text { Universitas Indonesia }\end{array}$ \\
\hline & \multicolumn{2}{|c|}{ Contents } & Pages \\
\hline Contents & \multicolumn{2}{|c|}{$\begin{array}{c}\text { Konservator } \\
\text { Masyarakat Aceh dan Filipina pasca bencana } \\
\text { Knowledge sharing }\end{array}$} & $\begin{array}{l}1 \\
2 \\
3\end{array}$ \\
\hline Keyword & \multicolumn{3}{|c|}{ Konservator; konservasi, pasca bencana; } \\
\hline
\end{tabular}

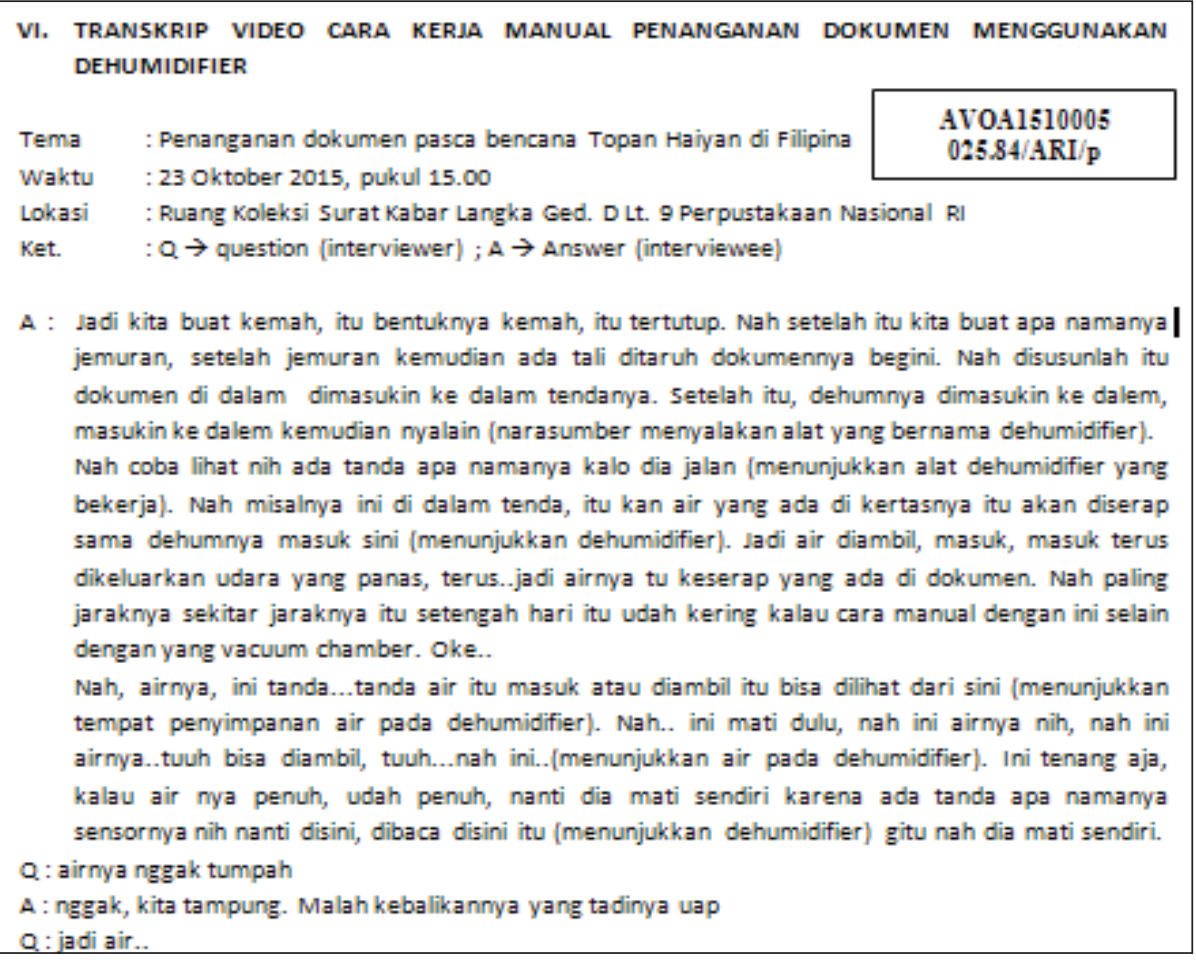

Gambar 8. Transcript contents III

Tabel 5. Daftar Transcript Contents III

\begin{tabular}{|c|c|c|c|c|}
\hline Project name & \multicolumn{4}{|c|}{ Penanganan Dokumen Pasca Bencana Topan Haiyan di Filipina } \\
\hline Number & \multicolumn{4}{|c|}{ AVOA1510005 } \\
\hline File name & \multicolumn{2}{|c|}{$\begin{array}{c}\text { Penanganan Dokumen Menggunakan } \\
\text { Dehumidifier }\end{array}$} & Video date & Oktober 2015 \\
\hline Interviewee & Narasumber & Gender & & Laki-Laki \\
\hline Interviewer & $\mathrm{Y}, \mathrm{Z}$ & Reviewer & & $\mathrm{Y}, \mathrm{Z}, \mathrm{X}$ \\
\hline \multirow[t]{2}{*}{$\begin{array}{l}\text { Subject classification } \\
\text { code }\end{array}$} & \multicolumn{2}{|c|}{ 025.84/ARI/p } & Video place & $\begin{array}{l}\text { Ruang koleksi surat kabar } \\
\text { langka, Ged. D lantai } 9\end{array}$ \\
\hline & \multicolumn{3}{|c|}{ Contents } & Pages \\
\hline Contents & \multicolumn{3}{|c|}{$\begin{array}{c}\text { Cara kerja manual penanganan dokumen } \\
\text { menggunakan dehumidifier }\end{array}$} & 1,2 \\
\hline Keyword & \multicolumn{4}{|c|}{ Dehumidifier, Dokumen } \\
\hline
\end{tabular}


Tabel 6. Biodata Narasumber

\begin{tabular}{|c|c|c|c|}
\hline Nama kegiatan & \multicolumn{3}{|c|}{ Penanganan Dokumen Pasca Bencana Topan Haiyan di Filipina } \\
\hline Nama & Narasumber & Tanggal lahir & 9 Agustus 19xx \\
\hline Alamat & $\begin{array}{c}\text { Griya sarua } \\
\text { permai blok G } \\
\text { no.xxxx }\end{array}$ & Tempat lahir & $\mathrm{xx}$ \\
\hline Telepon & 0856xxxxxx & Agama & $\mathrm{xx}$ \\
\hline \multirow{3}{*}{ Pendidikan } & \multirow{3}{*}{$\begin{array}{c}\text { Sarjana Kimia } \\
\text { Universitas } \\
\text { Gadjah Mada }\end{array}$} & Status & $\mathrm{xx}$ \\
\hline & & Pekerjaan & $\begin{array}{l}\text { Conservator } \\
\text { Perpusnas RI }\end{array}$ \\
\hline & & Jumlah anak & $\mathrm{x}$ orang \\
\hline \multirow{8}{*}{ Resume dan aktivitas } & Year & \multicolumn{2}{|c|}{ Aktivitas } \\
\hline & \multirow{2}{*}{1999} & \multicolumn{2}{|c|}{$\begin{array}{l}\text { Menempuh pendidikan sarjana kimia di } \\
\text { Universitas Gadjah Mada, Yogjakarta }\end{array}$} \\
\hline & & \multicolumn{2}{|c|}{$\begin{array}{l}\text { Asisten dosen Kimia Fisik, Universitas Gadjah } \\
\text { Mada, Yogjakarta }\end{array}$} \\
\hline & 2003 & \multicolumn{2}{|c|}{$\begin{array}{l}\text { Supervisor Research and Development, } \\
\text { PT Unilever Indonesia }\end{array}$} \\
\hline & 2005 & \multicolumn{2}{|c|}{$\begin{array}{c}\text { Foreman Wet Process, departemen produksi, PT } \\
\text { Frisian Flag Indonesia }\end{array}$} \\
\hline & 2008 & \multicolumn{2}{|c|}{$\begin{array}{l}\text { Officer Marketing, kantor pusat operasional, Bank } \\
\text { Muamalat Indonesia }\end{array}$} \\
\hline & 2009 & \multicolumn{2}{|c|}{$\begin{array}{l}\text { Conservator pusat preservasi, Perpustakaan } \\
\text { Nasional RI }\end{array}$} \\
\hline & 2015 & \multicolumn{2}{|c|}{$\begin{array}{l}\text { Menjalani pendidikan Pascasarjana Ilmu Informasi } \\
\text { dan Perpustakaan, Universitas Indonesia, Jakarta }\end{array}$} \\
\hline
\end{tabular}

\section{HASIL DAN PEMBAHASAN}

Dengan menganalisa hasil rekaman wawancara dan membuat langsung video yang dipraktekkan oleh narasumber bayak sekali manfaat yang diperoleh dari oral histori dan oral testimoni tentang bagaimana manajemen bencana pada perpustakaan dan arsip terutama apabila bencana telah terjadi yaitu disaster recovery. Apabila diperhatikan memang ilmu ini telah lama ada dan sangat pesat berkembang pada negara-negara maju terutama yang sering mengalami bencana seperti Amerika dan Jepang, namun tidak atau dikatakan sedikit berkembang untuk negara Indonesia. Boomingnya ilmu ini terjadi setelah tsunami aceh yang terjadi pada tahun 2004 yang kemudian negara mulai menyadari betapa pentingnya berbagai pihak terutama kalangan akademisi dan lembaga pemerintah membangun suatu sistem manajemen bencana yang dimulai dari mitigasi, persiapan, respon dan pemulihan. Penanganan setelah bencana atau pemulihan melibatkan semua operasi restorasi dari koleksi baik dengan cara manual maupun massal dan dilakukan dengan cepat.

Jika melihat peta konsep dari apa yang diceritakan oleh narasumber maka perencanaan tentang apa yang akan dilakukan merupakan hal pertama yang paling penting dengan 
mengumpulkan data-data kerusakan hingga menentukan prioritas data koleksi dan membuat rencana kerja. Dokumen yang direstorasi tidak mungkin akan kembali ke dalam bentuk yang sama, namun masih dapat diselamatkan dengan cara yang benar. Perlu diingat bahwa terdapat tiga hal utama yang menjadi faktor penting suksesnya proyek pemulihan yaitu pertama, tersedianya dana, kedua, fasilitas dan ketiga, orang berpengalaman yang menangani.

Ketersediaan dana sangat besar memungkinkan program yang dijalankan dapat berlangsung. Ketika terjadi bencana maka sumberdaya yang dimiliki di lokasi bencana akan semakin jarang dan mahal. Dana secara otomatis akan diperoleh dari luar lokasi bencana, untuk transportasi, membawa bahan dan barang, menyewa orang bekerja, bahan bakar, makan dan minum, tempat tinggal, dan lain-lain. Pastikan bahwa terdapat sumber dana yang cukup untuk dapat memenuhi kebutuhan di lokasi sehingga relawan tidak kesulitan dalam menjalankan misinya. Kedua adalah fasilitas yang memadai, proyek dalam pemulihan bencana biasanya dilakukan dengan cara yang massal sehingga membutuhkan alat berat berupa frezee dry vacuum chamber yang dapat membekukan cairan dan kotoran yang menempel kemudian hilang melalui proses sumblimasi langsung tanpa pencairan. Narasumber menjelaskan proses penggunaann alat tersebut dengan diagram sebagai berikut.

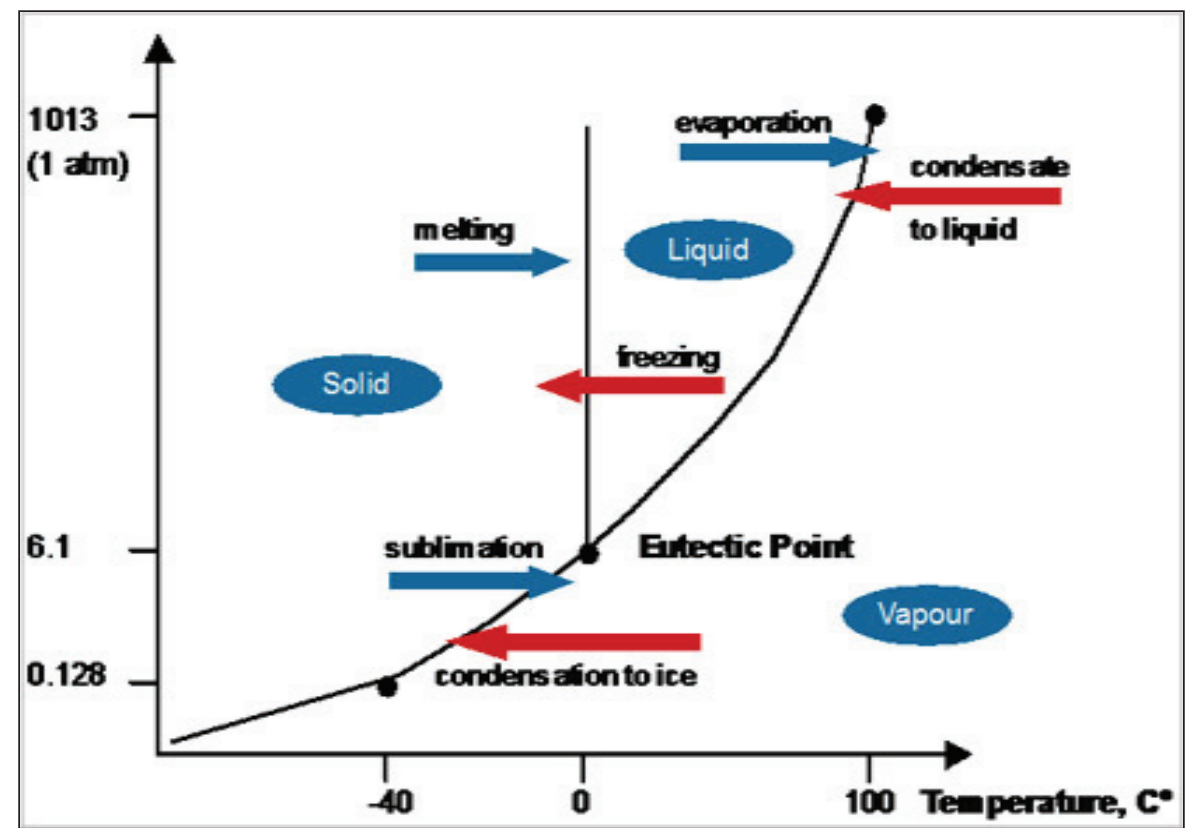

Gambar 9. Modifikasi fase air yang membeku tersublimasi menjadi gas (National Archives and Records Administration, LOC, 2016)

Dengan melihat gambar di atas, maka air tidak perlu mengalami proses fase cair dan dapat langsung menguap menjadi gas sehingga tidak lagi merusak dan menempel pada dokumen. Penggunaan alkohol yang dicampur dengan air sebelum memasukkan dokumen ke dalam mesin adalah cara yang terbaik. Apabila fasilitas ini tidak didapatkan dengan bantuan dari luar maka pekerjaan pemulihan dapat dilakukan secara manual yang banyak dijelaskan pada gambar-gambar melalui pengeringan udara pada suhu kamar dengan kipas angin atau memakai dehumudifier. Menjaga kebersihan dokumen dengan membebaskan himpitan satu persatu dari lembar yang lain, plastik dan cover sebaiknya dilakukan sesegera mungkin agar jamur tidak berkembang dengan cepat. Ketiga adalah adanya orang yang berpengalaman dalam melakukan penanganan dokumen setelah bencana karena ahli ini memiliki kapabilitas yang sesuai tentang treatment terbaik terhadap dokumen. Penanganan dan konsultasi yang salah tidak hanya akan membuat dokumen semakin hancur namun kondisi lingkungan di sekitarnya juga akan tekena dampak seperti tumbuhnya jamur pada ruangan. Sang ahli akan banyak berdiskusi dan memberi masukan tentang bagaimana menangani pemulihan yang efektif dan efisien, sebagai contoh ketika dokumen tidak lagi dapat bertahan lama hingga berhari-hari karena serangan jamur yang dahsyat dan bisa menghancurkan dokumen sehingga jamur harus dimatikan menggunakan alkohol, namun ketika alkohol di sana 
sangat sulit didapatkan maka ia akan berpikir memasukkan dokumen ke dalam freezer yang akan menghentikan pertumbuhan jamur. Pemanfaatan freezer dapat dilakukan dari berbagai sumber yang ada seperti pabrik es krim, pengolahan ikan, pembuatan es, dan lain-lain.

Terdapat banyak sekali manfaat dalam proses penangkapan pengetahuan ini. Dari pengalaman dan kesaksian (oral testimony) langsung yang telah terjadi bahwa masyarakat Filipina sudah melakukan proses enkapsulasi dalam setiap sertifikasinya namun penempatan posisi kantor penyimpanan dokumen dapat dikatakan tidak sesuai sebagaimana mestinya dikarenakan dekat dengan laut dan posisi yang berada di bawah permukaan laut.

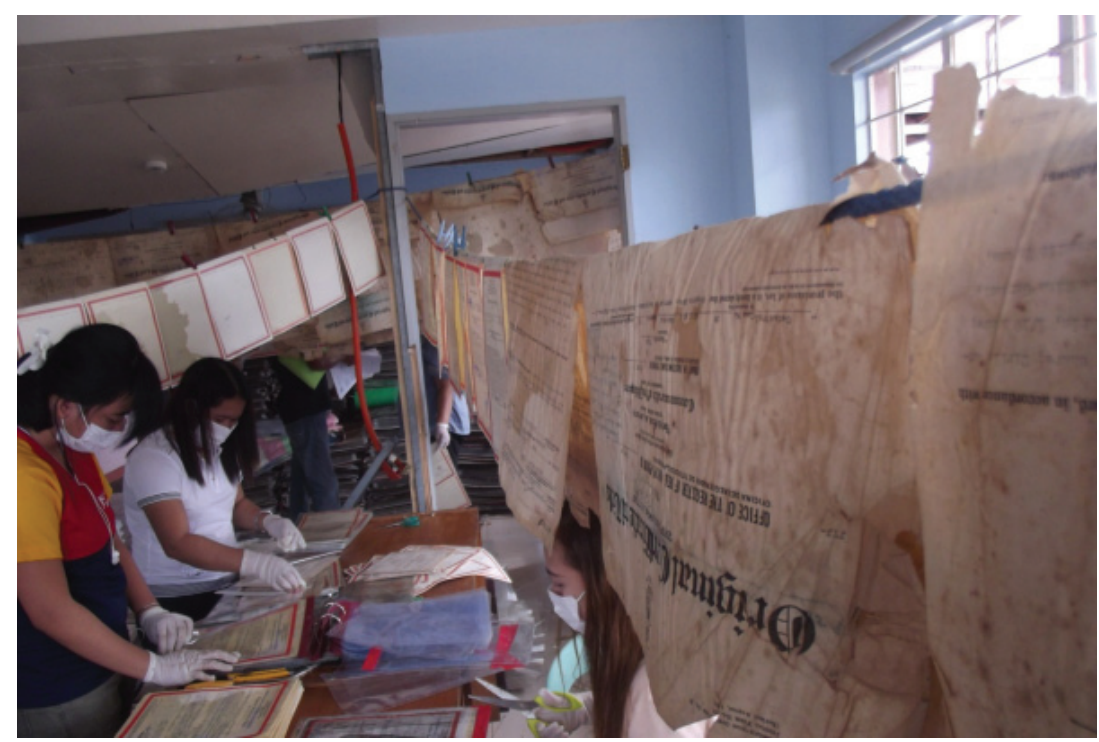

Gambar 10. Pekerja lokal yang membuka dokumen dari plastik kemudian menaruhnya di atas tali dan dikeringkan pada suhu kamar secara perlahan

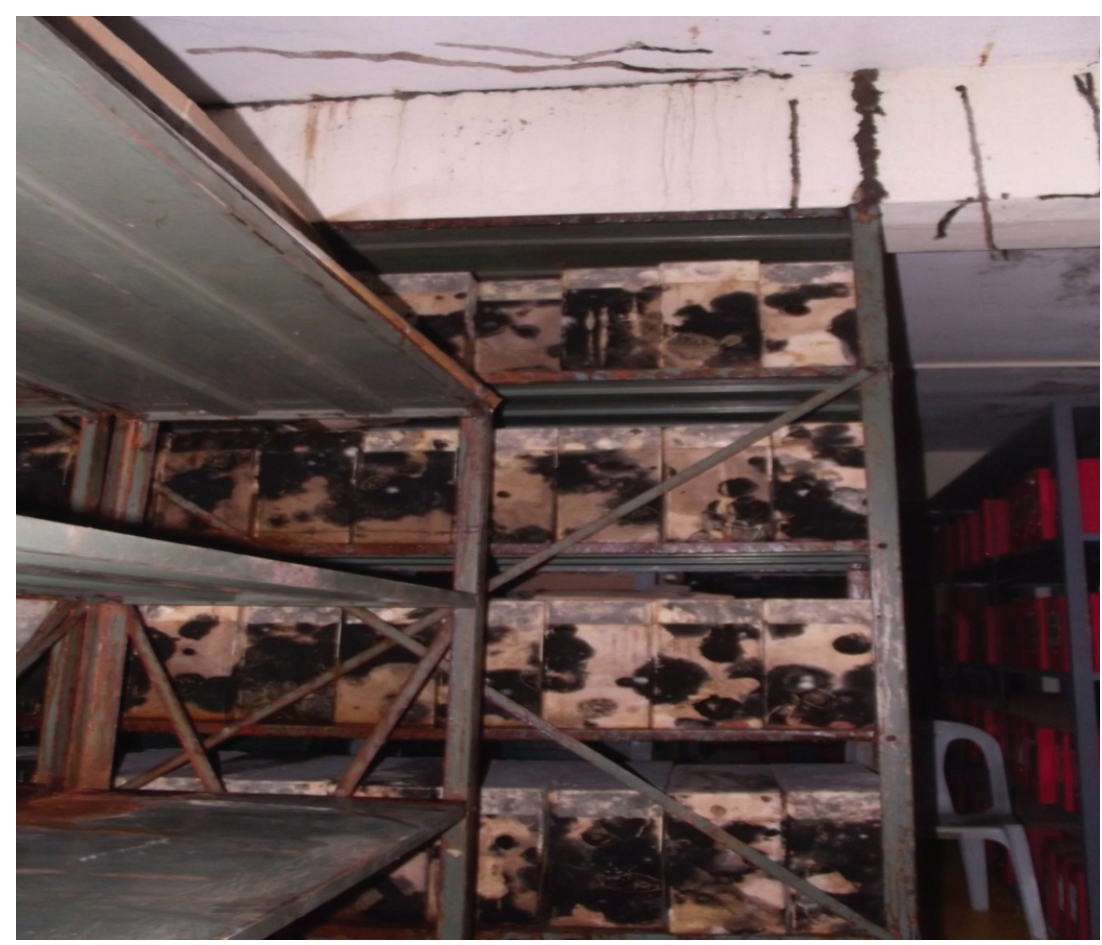

Gambar 7. Jamur yang sudah berkembang pada boks hingga masuk ke dokumen dan tumbuh juga pada lantai berikut rak logamnya. Kondisi yang lembab, banyak air, gelap, dingin, tidak ada sirkulasi udara sangat menguntungkan jamur untuk dapat tumbuh di ruang tersebut 
Menjaga keselamatan pekerja dan relawan merupakan hal terpenting ketika pekerjaan dilakukan. Dikarenakan kondisi lingkungan yang serba minim dan kurang menguntungkan dari berbagai aspek maka perencana akan berpikir matang dalam menilai keselamatan perlu dilakukan setiap saat sebelum terjadi kesalahan. Bekerja dalam tim, saling bahu membahu adalah hal mudah dan terbaik untuk mendapatkan solusi. Mempekerjakan penduduk yang ada di sekitar lokasi untuk dapat berpartisipasi dengan memberi upah adalah salah satu bagaimana mereka melupakan kesedihan dan tetap memperoleh uang untuk melanjutkan hidup. Terdapat banyak cara yang dapat dilakukan di luar dari proses penanganan langsung, seperti melakukan pembuatan poster dan penyebarannya kepada penduduk sekitar tentang proses penanganan bencana. Mengundang kantor berita baik nasional maupun internasional untuk meliput kegiatan yang dilakukan selama pemulihan dokumen sehingga dunia luar akan menilai hal yang positif dan tersadar betapa pentingnya menjaga dokumen mereka.

Peran serta pemerintah pusat dan lokal sangat dibutuhkan dalam hal ini sebagai koordinator dan dapat memastikan keselamatan dan keamanan para relawan selama di sana. Budaya dan kebiasaan yang ada pada lokasi dipastikan berbeda dengan budaya pendatang sehingga orang asing dituntut untuk dapat beradaptasi dan toleransi kepada penduduk asli. Penanganan bencana dalam skala yang besar pada dasarnya membutuhkan cara yang bersifat massal dan cepat sehingga peran pemerintah sangat dibutuhkan untuk saling berkoordinasi dengan berbagai pihak asing maupun swasta. Sebagai contoh peminjaman freezer pihak swasta pada industri ice cream oleh pemerintah atau membawa dokumen tersebut melewati batas negara untuk ditangani secara massal dengan freezer vacuum chamber di Negara lain. Seperti halnya kebutuhan lainnya dokumen adalah nyawa ke dua bagi manusia karena segala yang manusia upayakan selama hidupnya terwakili dalam dokumen, maka sudah seharusnya pula masyarakat memahami pentingnya menjaga dan melestarikan dokumennya. Lebih lanjut ilmu informasi dan perpustakaan juga berperan serta mengembangkan pengetahuan dalam merawat dan memperbaiki dokumen (preservasi) tidak hanya dalam bentuk informasinya saja namun juga fisik artefaknya.

\section{KESIMPULAN}

Artikel penelitian ini memberikan kontribusi dalam literatur manajemen pengetahuan dengan memperkenalkan dan mendefinisikan proses pengetahuan informal dan menghubungkan dua proses inti yang diusulkan oleh Nonaka dan Takeuchi dalam model SECI. Proses sosialisasi dan internalisasi adalah dua pola utama yang mengkonversi pengetahuan tacit ke pengetahuan eksplisit dan sebaliknya, ada kebutuhan untuk lebih memahami dan menentukan proses-proses pengetahuan informal. Tulisan ini menawarkan salah satu pemandangan segar dalam proses pengetahuan informal seorang ahli yang memiliki pengetahuan dan pengalaman mendalam dalam rangka meningkatkan kemampuan manajemen pengetahuan sebuah organisasi. Seorang ahli atau ilmuwan dapat dipastikan memiliki banyak pengetahuan dan pengalaman tacitnya yang kemungkinan besar tidak tertuliskan atau terungkapkan secara sitematis, oleh karena itu makalah sejatinya dapat memberikan salah satu contoh bagaimana cara menangkap pengetahuan dan meningkatkan tahapan dalam SECI menuju tahap selanjutnya. Setidaknya terdapat dua pengetahuan yang dapat diungkapkan dalam artikel ini yaitu berupa pengetahuan tentang metode atau langkah-langkah dalam menangkap pengetahuan dan membuatnya menjadi eksplisit dan pengetahuan tentang manajemen perbaikan dokumen akibat bencana alam yang masuk dalam ranah preservasi ilmu informasi dan perpustakaan.

\section{SARAN DAN UCAPAN TERIMA KASIH}

Kami ucapkan syukur dan terimakasih atas Allah SWT yang telah memberikan segala rahmatnya sehingga memperkaya ilmu dan pengetahuan terhadap narasumber dan dari sanalah semuanya berasal hingga terciptanya artikel ini; kepada team yang bahu membahu dan saling mendukung satu sama lain mengisi artikel ini; dan kepada dosen kami yang mengajar mata kuliah presevasi pengetahuan Prof. Sulistyo-Basuki dan Dr. Tamara karena dari beliau-lah kami memiliki banyak pengetahuan dan dapat terus melestarikannya. 


\section{DAFTAR PUSTAKA}

Clement, David.1985. Preservation of Library Collection. PX: UNESCO. Conservation and preservation at the National Library of Indonesia: A report by the International Revew Team for conservation and preservation. 1989. Jakarta: Perpustakaan Nasional RI.

Dalkir, K. 2013. Knowledge Management in Theory and Practice. Routledge.

Djulianto Susantio. 2010. Profesi Konservator, Langka Karena Dana.

Gourlay, S. 2004. A Critical Analysis of Nonaka's Model of Knowledge Dynamics. Electronic Journal of Knowledge Management, 8.

Greenfield, Jane. 1984. Books: Their Care And Repair. London: Library of Conggress.

Hoe, S. L. 2006. Tacit knowledge, Nonaka and Takeuchi SECI Model and Informal Knowledge Processes. International Journal of Organization Theory and Behavior, 9(4), 490.

Li, B., Zhang, J., \& Zhang, X. 2013. Knowledge Management and Organizational Culture: An Exploratory Study. Creative and Knowledge Society, 3(1), 65-77.

Razak, Muhammadin. 2012. Rancangan Naskah Akademis tentang Jabatan Fungsional Konservator. Jakarta: Perpustakaan Nasional RI.

Swain, E. 2003. Oral History in The Archives: Its Documentary Role in The Twenty-First Century. The American Archivist, 66(1), 139-158.

Tee, M. Y., \& Lee, S. S. 2013. Advancing Understanding Using Nonaka's Model of Knowledge Creation and Problem-Based Learning. International Journal of Computer-Supported Collaborative Learning, 8(3), 313-331.

USC Shoah Foundation Institute. 2007. Interviewer Guidelines. Los Angelos: Univeristy of Southern California College of Letters, Arts \& Sciences. 